\title{
Adverse Event Group Identifier
}

National Cancer Institute

\section{Source}

National Cancer Institute. Adverse Event Group Identifier. NCI Thesaurus. Code C83204.

A character or string that represents an adverse event group. 